\title{
Tetraammine Ruthenate Complexes: Cationic SAMs for Cytochrome c Recognition
}

\author{
Solange de Oliveira Pinheiro, ${ }^{a}$ Francisco O. N. da Silva, ${ }^{a}$ Idalina M. M. de Carvalho, \\ Luiz G. de França Lopes, ${ }^{a}$ Marcia L. A. Temperini, ${ }^{b}$ Gustavo F. S. de Andrade, ${ }^{b}$ \\ Ícaro de Sousa Moreira ${ }^{*, a}$ and Izaura C. N. Diógenes ${ }^{*, a}$ \\ ${ }^{a}$ Departamento de Química Orgânica e Inorgânica, Universidade Federal do Ceará, CP 12200, \\ 60455-760 Fortaleza-CE, Brazil \\ ${ }^{b}$ Instituto de Química de São Paulo, Universidade de São Paulo, CP 26077, \\ 05508-900 São Paulo-SP, Brazil
}

\begin{abstract}
O processo redox da metaloproteína cyt c foi observado através da utilização de eletrodos de ouro modificados com os complexos $\left[\mathrm{Ru}(\mathrm{CNPy})\left(\mathrm{NH}_{3}\right)_{4}(1,4-\mathrm{dt})\right]^{2+}$ e $\left[\mathrm{Ru}(\mathrm{CNPy})\left(\mathrm{NH}_{3}\right)_{4}(\mathrm{pyS})\right]^{2+}$, onde $\mathrm{CNPy}=4$-cianopiridina, pyS = 4-mercaptopiridina e 1,4$\mathrm{dt}=$ ditiano. Os valores dos potenciais redox observados indicam a forma in natura da proteína. A forma dos voltamogramas, todavia, é dependente da conformação do complexo modificador sobre a superfície que, por sua vez, foi determinada por SERS. Os potenciais de dessorção redutiva, observados em $-0,52$ e $-0,64 \mathrm{~V}$ vs $\mathrm{Ag}|\mathrm{AgCl}| \mathrm{Cl}^{-}$para os complexos $\left[\mathrm{Ru}(\mathrm{CNPy})\left(\mathrm{NH}_{3}\right)_{4}(1,4-\mathrm{dt})\right]^{2+}$ e $\left[\mathrm{Ru}(\mathrm{CNPy})\left(\mathrm{NH}_{3}\right)_{4}(\mathrm{pyS})\right]^{2+}$, respectivamente, são indicativos do tipo de ligação com a superfície e da capacidade $\pi$ retiradora do ligante CNpy.
\end{abstract}

The redox process of the cyt c metalloprotein was assessed by the cationic SAMs formed with $\left[\mathrm{Ru}(\mathrm{CNPy})\left(\mathrm{NH}_{3}\right)_{4}(1,4-\mathrm{dt})\right]^{2+}$ and $\left[\mathrm{Ru}(\mathrm{CNPy})\left(\mathrm{NH}_{3}\right)_{4}(\mathrm{pyS})\right]^{2+}$ complexes on gold, where CNPy $=4$-cyanopyridine, pyS $=4$-mercaptopyridine and 1,4-dt $=$ dithiane. The observed cyt $\mathrm{c}$ redox potentials are indicative of the native protein form. The voltammograms, however, were observed to be affected by the conformation of the modifiers, determined by SERS spectroscopy. The $\left[\mathrm{Ru}(\mathrm{CNPy})\left(\mathrm{NH}_{3}\right)_{4}(\mathrm{pyS})\right]^{2+}$ complex, which exhibits trans conformation on the surface, presented a well-defined voltammogram. On the other hand, the gauche conformation of the $\left[\mathrm{Ru}(\mathrm{CNPy})\left(\mathrm{NH}_{3}\right)_{4}(1,4-\mathrm{dt})\right]^{2+} \mathrm{SAM}$ seems to make the assessment of the cyt c hET reaction difficult. The reductive desorption potentials, at -0.52 and $-0.64 \mathrm{~V} v s \mathrm{Ag}|\mathrm{AgCl}| \mathrm{Cl}^{-}$for the $\left[\mathrm{Ru}(\mathrm{CNPy})\left(\mathrm{NH}_{3}\right)_{4}(1,4-\mathrm{dt})\right]^{2+}$ and $\left[\mathrm{Ru}(\mathrm{CNPy})\left(\mathrm{NH}_{3}\right)_{4}(\mathrm{pyS})\right]^{2+}$ SAMs, respectively, are indicative of the bonding mode with the surface and the $\pi$ withdrawing capability of the CNpy ligand.

Keywords: self-assembled monolayers, cytochrome c, tetraamineruthenate complexes, sulfur ligands

\section{Introduction}

Modern coordination chemistry is expanding the ability to mimic form and structure in biology aiming to recognize and establish the mechanism of electron-transfer (ET) processes in vivo. In this sense, metallic surfaces spontaneously modified by specific molecules have been frequently used to build highly ordered monolayers, which facilitate the assessment of the heterogeneous electrontransfer (hET) reactions of metalloproteins. Among these, cytochrome c (cyt c) is a membrane ET protein that plays an important role not only in basic biological processes

*e-mail: izaura@dqoi.ufc.br; icarosm@dqoi.ufc.br but also in many technological applications. ${ }^{1-4}$ Although many efforts have been made on the investigation of the ET mechanism of the cyt c protein, it continues to be a challenge for researches. In fact, since the original work published by Eddowes and Hill, ${ }^{5}$ over 60 bifunctional organic and inorganic modifiers have been used in an attempt to assess and understand the mechanism of the fast cyt $\mathrm{c}$ hET reaction. ${ }^{6-8}$ As a result, modifiers that are adsorbed at a perpendicular orientation in relation to the metallic surface and that contain an anionic or weakly basic end were proposed to successful assess the cyt c $\mathrm{hET}$ reaction. In fact, it is currently suggested, although without direct evidence, that the lysine patches may have an influence on the orientation and conformation of the 
cyt c on Self-Assembled Monolayers (SAMs). Some authors claim that one must focus on the strength of a charged surface to ensure both the desired orientation and native conformation of the cyt c protein. ${ }^{9}$

Aiming to contribute to the understanding of the ET mechanism of metalloproteins such as cyt c, the electrochemical process of this species in physiological medium was studied by using polycrystalline gold surfaces modified with inorganic complexes of the type trans$\left[\mathrm{Ru}(\mathrm{CNpy})\left(\mathrm{NH}_{3}\right)_{4}(\mathrm{~L})\right]^{2+}$, where CNpy = 4-cyanopyridine, $\mathrm{L}=1$,4-dithiane (1,4-dt), 4-mercaptopyridine (pyS). The key point is to evaluate the effect of the positive net charge of the complexes synthesized, $\left[\mathrm{Ru}(\mathrm{CNpy})\left(\mathrm{NH}_{3}\right)_{4}(1,4-\mathrm{dt})\right]^{2+}$ and $\left[\mathrm{Ru}(\mathrm{CNpy})\left(\mathrm{NH}_{3}\right)_{4}(\mathrm{pyS})\right]^{2+}$, on the cyt c electrochemical response.

\section{Experimental}

\section{Apparatus}

The chromatographic analyses were performed with a Shimadzu liquid chromatograph equipped with a model LC-10AD pump and a SPD-M10A UV-Visible photodiodearray detector with a CBM-10AD interface. An ODS column ( $250 \mathrm{~mm} \times 4.6 \mathrm{~mm}$ id., $5 \mu \mathrm{m}$ particles; from Altech) was used with an isocratic elution with 30:70 acetonitrilewater containing $0.1 \%$ HTFA, $\mathrm{pH}=3.7$. The chromatograms were taken at a constant flow-rate of 1.0

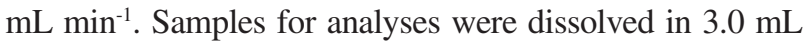
of the mobile phase and $5 \mu \mathrm{L}$ of volumes were injected.

Electrochemical experiments were performed on a BAS 100W electrochemical analyzer (Bioanalytical Systems-BAS, West Lafayette, IN) at $25 \pm 0.2^{\circ} \mathrm{C}$. A threeelectrode glass cell was used with two platinum disks of $0.126 \mathrm{~cm}^{2}$ geometrical area, each of which used as working and auxiliary electrodes in the characterization of the complexes. An $\mathrm{Ag} \mid \mathrm{AgCl}$ electrode, for which the ferrocene/ferrocenium $\left(\mathrm{Fc}^{+/ 0}\right)$ redox process was observed at $0.19 \mathrm{~V}$ in acetonitrile containing $0.1 \mathrm{~mol} \mathrm{~L}^{-1}$ tetrabutylammonium perchlorate (TBAP), was prepared $1 \mathrm{~h}$ prior to the beginning of the experiments and used as reference electrode. The half-wave formal potentials $\left(\mathrm{E}_{1 / 2}\right)$ of the $\mathrm{Ru}^{\mathrm{III} / \mathrm{II}}$ redox process of the complexes isolated were determined from the average value between the anodic $\left(E_{a}\right)$ and cathodic $\left(E_{c}\right)$ peak potentials obtained by cyclic voltammetry. The reductive desorption potentials $\left(E_{r d}\right)$ of the monolayers were obtained by linear sweep voltammetry (LSV) at $0.05 \mathrm{~V} \mathrm{~s}^{-1}$ in a Teflon cell containing $0.5 \mathrm{~mol} \mathrm{~L}^{-1} \mathrm{KOH}$ aqueous solution. This solution was degassed with argon for $30 \mathrm{~min}$ before the measurements and a potential range from -0.2 to $-1.2 \mathrm{~V}$ vs $\mathrm{Ag}|\mathrm{AgCl}| \mathrm{Cl}^{-}$ (a $3.5 \mathrm{~mol} \mathrm{~L}^{-1} \mathrm{KCl} \mathrm{Ag|AgCl} \mid \mathrm{Cl}^{-}$reference electrode purchased from BAS was used) was applied. The electrochemical experiments with cyt $\mathrm{c}$ were carried out by using a three-electrode glass cell containing $0.1 \mathrm{~mol}$ $\mathrm{L}^{-1}$ buffer phosphate $\left(\mathrm{KH}_{2} \mathrm{PO}_{4}\right), \mathrm{pH}=7.0$. For these protein studies, a polycrystalline gold surface of $0.031 \mathrm{~cm}^{2}$ geometrical area modified with the complexes, an $\mathrm{Ag}|\mathrm{AgCl}| \mathrm{Cl}^{-}\left(3.5 \mathrm{~mol} \mathrm{~L}^{-1} \mathrm{KCl}, \mathrm{BAS}\right)$ and a gold flag were used as working, reference and auxiliary electrodes, respectively. The polishing procedure of the gold surfaces was made as described by $\mathrm{Qu}$ et al. ${ }^{10}$ These electrodes were mechanically polished with alumina paste of different grade to a mirror finish, rinsed and sonicated (10 min) in Milli-Q water. The electrode was then immersed in a freshly prepared "piranha solution" (3:1 concentrated $\mathrm{H}_{2} \mathrm{SO}_{4} / 30 \% \mathrm{H}_{2} \mathrm{O}_{2}$; CAUTION: Piranha solution is a high oxidant solution that reacts violently with organic compounds), rinsed exhaustively with water, and sonicated again. The cleanness was evaluated by comparison of the i-E curve obtained in a $0.5 \mathrm{~mol} \mathrm{\textrm {L } ^ { - 1 }}$ $\mathrm{H}_{2} \mathrm{SO}_{4}$ solution with the well-established one for a clean gold surface. ${ }^{11}$ After this procedure, the surface modification was made by immersing the gold electrodes in a $2.0 \times 10^{-3} \mathrm{~mol} \mathrm{~L}^{-1}$ aqueous solution of the $\left[\mathrm{Ru}(\mathrm{CNpy})\left(\mathrm{NH}_{3}\right)_{4}(\mathrm{pyS})\right]^{2+}$ and $\left[\mathrm{Ru}(\mathrm{CNpy})\left(\mathrm{NH}_{3}\right)_{4}(1,4-\mathrm{dt})\right]^{2+}$ complexes for 30 minutes. This immersion time was used because, considering the experimental conditions, the cyt c hET redox process was observed with best resolution.

The Raman and SERS (Surface-Enhanced Raman Scattering) spectra were acquired on a Renishaw Raman System 3000 equipped with an Olympus microscope (BTH) with an $80 \mathrm{x}$ objective to focus the laser beam on the sample. As exciting radiation $\left(1_{0}\right)$, the $632.8 \mathrm{~nm}$ line from an aircooled He-Ne (Spectra Physics) laser was used. The laser power at sample was $c a .1 \mathrm{~mW}$. A gold electrode with 0.2 $\mathrm{cm}^{2}$ geometrical area, used as SERS substrate, was activated by performing successive oxidation-reduction cycles (ORC) in a 0.1 mol $\mathrm{L}^{-1} \mathrm{KCl}$ solution from -0.2 to $1.3 \mathrm{~V} v s$. $\mathrm{Ag}|\mathrm{AgCl}| \mathrm{Cl}^{-}$. The activation procedure of the SERS substrates was performed in an electrochemical system PAR 263 potentiostat-galvanostat from EG\&G.

Unless otherwise specified, all the potentials referred in the text are quoted in relation to the $\mathrm{Ag}|\mathrm{AgCl}| \mathrm{Cl}^{-}$(3.5 mol L ${ }^{-1} \mathrm{KCl}, \mathrm{BAS}$ ) reference electrode at $25{ }^{\circ} \mathrm{C}$.

\section{Chemicals}

The water used throughout was purified from a Milli-Q water system (Millipore Co.). The organic solvents (Merck and Aldrich) of spectroscopic grade were used as received. The purification of acetonitrile for electrochemical work was 
performed as before. ${ }^{11}$ The 1,4-dithiane (1,4-dt), 4mercaptopyridine (pyS), 4-Cyanopyridine (CNpy), $\mathrm{KCl}$, $\mathrm{KOH}$ and $\mathrm{KH}_{2} \mathrm{PO}_{4}$ compounds, from Aldrich, and high-purity $\mathrm{H}_{2} \mathrm{SO}_{4}$, from Merck, were used without further purification. Horse heart cytochrome c (95\%, Sigma) was purified as described elsewhere. ${ }^{12}$ The trans- $\left[\mathrm{Ru}(\mathrm{CNpy})\left(\mathrm{NH}_{3}\right)_{4}(\mathrm{~L})\right]\left(\mathrm{PF}_{6}\right)_{2}$ ( $\mathrm{L}=1,4-\mathrm{dt}$ or pyS) complexes were synthesized according to the literature procedures. ${ }^{13-15}$ The HPLC (high performance liquid chromatography) chromatograms of the complexes presented just one peak, indicating the high level purity of the isolated compounds. The complexes were also characterized by elemental analysis, electronic spectroscopy in the ultraviolet and visible (UV-Vis) regions, and electrochemical measurements (cyclic voltammetry). For the $\left[\mathrm{Ru}(\mathrm{CNpy})\left(\mathrm{NH}_{3}\right)_{4}(1,4-\mathrm{dt})\right]\left(\mathrm{PF}_{6}\right)_{2} .2 \mathrm{H}_{2} \mathrm{O}$ complex: Anal. Calc.: C: $16.69 ; \mathrm{H}: 3.92 ; \mathrm{N}: 11.68$; S: 8.91\%. Found: C: 15.63 ; H: 4.01; N: 12.47 ; S: 9.49\%. Yield: $89 \%$. UV-Vis in acetonitrile: $\lambda=516$ and $250 \mathrm{~nm} . \mathrm{E}_{1 / 2}\left(0.1 \mathrm{~mol} \mathrm{~L}^{-1} \mathrm{TBAP}\right.$ in acetonitrile $)$ $=0.17 \mathrm{~V}$. For the $\left[\mathrm{Ru}(\mathrm{CNpy})\left(\mathrm{NH}_{3}\right)_{4}(\mathrm{pyS})\right]\left(\mathrm{PF}_{6}\right)_{2} \cdot 2 \mathrm{H}_{2} \mathrm{O}$ complex: Anal. Calc.: C: 18.59 ; H: 3.40; N: $13.80 ;$ S: $4.51 \%$. Found: C: 18.01 ; H: 3.02; N: 12.20; S: 5.05\%. Yield: $80 \%$. UV-Vis in acetonitrile: $\lambda=546$ and $250 \mathrm{~nm}$. $\mathrm{E}_{1 / 2}\left(0.1 \mathrm{~mol} \mathrm{~L}^{-1}\right.$ TBAP in acetonitrile) $=0.50 \mathrm{~V}$. As for similar systems, the bands of lower energy in the UV-Vis spectra of both the complexes could be assigned ${ }^{15}$ to the metal-to-ligand chargetransfer (MLCT) transitions indicating the $\pi$-back-bonding interaction of the metal center.

\section{Results and Discussion}

\section{SERS results}

The ex situ SERS spectra of the monolayers formed on gold are illustrated in Figures 1 and 2. For correlation purposes, the normal Raman spectra of the CNpy, 1,4-dt and pyS ligands, and the $\left[\mathrm{Ru}(\mathrm{CNpy})\left(\mathrm{NH}_{3}\right)_{4}(1,4-\mathrm{dt})\right]\left(\mathrm{PF}_{6}\right)_{2}$ and $\left[\mathrm{Ru}(\mathrm{CNpy})\left(\mathrm{NH}_{3}\right)_{4}(\mathrm{pyS})\right]\left(\mathrm{PF}_{6}\right)_{2}$ complexes in the solid state are also presented.

The normal Raman spectrum of the $\left[\mathrm{Ru}(\mathrm{CNpy})\left(\mathrm{NH}_{3}\right)_{4}\right.$ $(1,4-\mathrm{dt})]\left(\mathrm{PF}_{6}\right)_{2}$ complex (curve c) is dominated by the bands of the CNpy ligand from 800 to $2200 \mathrm{~cm}^{-1}$. In this region, the $\mathrm{NH}$ symmetric and asymmetric deformations $\left(\delta_{\mathrm{NH}}\right)$ of the $\mathrm{NH}_{3}$ ligands ${ }^{16}$ are also observed at near 1290 and 1600 $\mathrm{cm}^{-1}$, respectively. The strong band observed around 1012 $\mathrm{cm}^{-1}$ in the normal Raman spectra of the free CNpy ligand and the $\left[\mathrm{Ru}(\mathrm{CNpy})\left(\mathrm{NH}_{3}\right)_{4}(1,4-\mathrm{dt})\right]\left(\mathrm{PF}_{6}\right)_{2}$ complex is assigned to the ring breathing mode of the pyridyl ring. ${ }^{17} \mathrm{The} \mathrm{C}-\mathrm{H}$ in plane bending is observed at $1194 \mathrm{~cm}^{-1}$. The coupled stretching modes $\left(\mathrm{v}_{\mathrm{C}=\mathrm{C}}+\mathrm{v}_{\mathrm{C}=\mathrm{N}}\right)$ of the pyridyl ring and the cyanide stretching vibration, $\mathrm{C} \equiv \mathrm{N}\left(\mathrm{v}_{\mathrm{CN}}\right)$, of the CNpy moiety are observed at 1600 and $2250 \mathrm{~cm}^{-1}$, respectively, in the

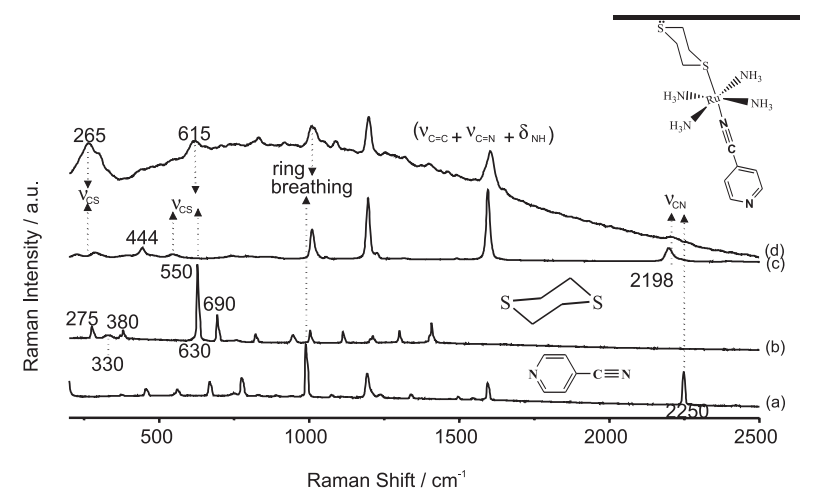

Figure 1. Normal Raman spectra in the solid state of (a) CNpy, (b) 1,4-dt, (c) $\left[\mathrm{Ru}(\mathrm{CNpy})\left(\mathrm{NH}_{3}\right)_{4}(1,4-\mathrm{dt})\right]\left(\mathrm{PF}_{6}\right)_{2}$ complex and (d) SERS spectrum of the $\left[\mathrm{Ru}(\mathrm{CNpy})\left(\mathrm{NH}_{3}\right)_{4}(1,4-\mathrm{dt})\right]^{2+}$ complex adsorbed on gold. $1_{0}=632.8$ $\mathrm{nm}$.

normal Raman spectrum of the free CNpy ligand (curve a). Upon coordination to the metal center (curve c), the $v_{\mathrm{CN}}$ shifts from 2250 to $2198 \mathrm{~cm}^{-1}$ indicating that the bonding occurs through the nitrile group of the CNpy ligand, as suggested in the representation inserted in Figure 1. Similar results were observed by Huang et al..$^{15}$ for the 4- and 3-cyanopyridines coordinated to the $\left[\mathrm{Ru}\left(\mathrm{NH}_{3}\right)_{5}\right]^{2+}$ metal center.

The observation of the $v_{\mathrm{CN}}$ mode in the SERS spectrum of the trans-[Ru(CNpy) $\left.\left(\mathrm{NH}_{3}\right)_{4}(1,4-\mathrm{dt})\right]^{2+}$ complex adsorbed on gold (curve d) at the same frequency (2198 $\mathrm{cm}^{-1}$ ) as that observed in the normal Raman spectrum (curve c) is an evidence that this group does not interact with the surface. The high similarity between the SERS and the Raman spectra (curves $\mathrm{c}$ and d) is consistent with the presence of the complex on the surface with its chemical integrity maintained even after adsorption. Based on surface selection rules, ${ }^{18}$ the intensification of the bands observed from 250 to $645 \mathrm{~cm}^{-1}$, assigned to the CS vibrational modes of the 1,4-dt ligand, ${ }^{19}$ in relation to the CNpy modes (particularly the $\mathrm{v}_{\mathrm{CN}}$ mode), ${ }^{17,20,21}$ suggests that the 1,4-dt molecule is closer to the gold surface than the CNpy moiety. The changes in the frequencies of the CS stretching bands, observed by comparing the SERS spectrum of the trans-[Ru(CNpy) $\left.\left(\mathrm{NH}_{3}\right)_{4}(1,4-\mathrm{dt})\right]^{2+}$ complex (curve d) with the normal Raman spectrum of the 1,4-dt ligand (curve b), suggest a gauche orientation ${ }^{22,23}$ with the complex partially tilted in relation to the gold surface, as illustrated in the Figure 1 inset. For the SAM formed with the 1,4-dt free ligand, a mixed gauche and trans orientation on the gold surface is proposed based on SERS studies. ${ }^{24}$ However when the SAM of the trans$\left[\mathrm{Ru}(\mathrm{CNPy})\left(\mathrm{NH}_{3}\right)_{4}(1,4-\mathrm{dt})\right]^{2+}$ complex is formed, the stable energetic state configuration on surface is gauche-oriented probably because this arrangement implies in a lower electrostatic repulsion between the positive adjacent molecules. 


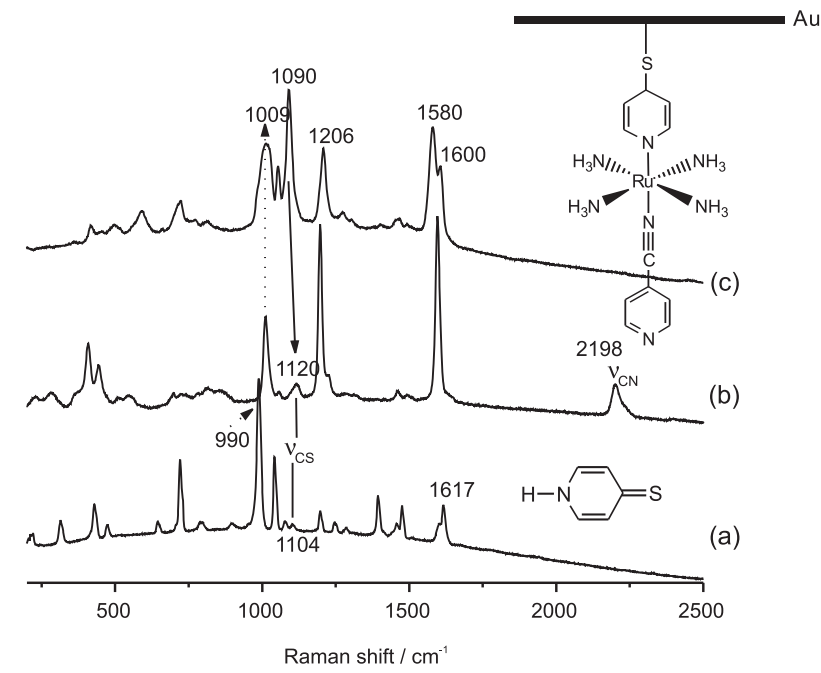

Figure 2. Normal Raman spectra of the (a) pyS and (b) $\left[\mathrm{Ru}(\mathrm{CNpy})\left(\mathrm{NH}_{3}\right)_{4}(\mathrm{pyS})\right]\left(\mathrm{PF}_{6}\right)_{2}$ complex in the solid state and (c) SERS spectrum of the $\left[\mathrm{Ru}(\mathrm{CNpy})\left(\mathrm{NH}_{3}\right)_{4}(\mathrm{pyS})\right]^{2+}$ complex adsorbed on gold. $1_{0}$ $=632.8 \mathrm{~nm}$.

For the pyS ligand, the signal observed at $1104 \mathrm{~cm}^{-1}$ in the normal Raman spectrum (curve a, Figure 2) is assigned to the ring breathing mode with a large character of the $\mathrm{C}=\mathrm{S}$ stretching vibration $\left(v_{\mathrm{CS}}\right) \cdot{ }^{25-27}$ This vibrational mode is currently assigned as X-sensitive band because of the sensibility toward changes in the ring trans substituent. ${ }^{25-27}$ Upon coordination (curve b), this vibrational mode shifts to $1120 \mathrm{~cm}^{-1}$ suggesting that the coordination occurs through the nitrogen atom of the pyridine moiety. As it can be seen from the SERS spectrum of the $\left[\mathrm{Ru}(\mathrm{CNpy})\left(\mathrm{NH}_{3}\right)_{4}(\mathrm{pyS})\right]^{2+}$ complex on gold (curve c, Figure 2), the $\mathrm{X}$-sensitive band shifts to $1090 \mathrm{~cm}^{-1}$ indicating a decrease in the double character of the $\mathrm{C}=\mathrm{S}$ bond as consequence of the adsorption to the surface through the sulfur atom of the pyS moiety. Also the intensity enhancement observed for this band, comparatively to the $\mathrm{n}_{\mathrm{CN}}$ band of the coordinated CNpy ligand, corroborates with this conclusion. These results suggest, based on the surface selection rules, ${ }^{18}$ that the pyS coordinated ligand is closer to the electrode surface than the CNpy moiety. The increase in intensity of the Xsensitive band also suggests a perpendicular arrangement of this adsorbate in relation to the surface normal ${ }^{7,26}$ as indicated by the Figure 2 inset. For this orientation, the adsorbate is expected to bind gold surface through sulfur $\mathrm{s}$ interaction. ${ }^{26,28}$ In fact, the strong affinity of thiol groups for gold surfaces is well documented in the literature. ${ }^{28,29}$

\section{Reductive desorption results}

The LSV desorption curves of the modified gold surfaces showed only one wave assigned ${ }^{30}$ to the electrode reaction $\mathrm{Ru}(\mathrm{CNpy})\left(\mathrm{NH}_{3}\right)_{4} \mathrm{RSAu}+\mathrm{e}^{-} \rightarrow \mathrm{Ru}(\mathrm{CNpy})\left(\mathrm{NH}_{3}\right)_{4}$ $\mathrm{RS}^{-}+\mathrm{Au}$, where $\mathrm{RS}=1,4-\mathrm{dt}$ or pyS. The reductive desorption potential $\left(\mathrm{E}_{\mathrm{rd}}\right)$ of this reaction is observed at 0.52 and $-0.64 \mathrm{~V}$ for the $\left[\mathrm{Ru}(\mathrm{CNpy})\left(\mathrm{NH}_{3}\right)_{4}(1,4-\mathrm{dt})\right]^{2+}$ and $\left[\mathrm{Ru}(\mathrm{CNpy})\left(\mathrm{NH}_{3}\right)_{4}(\mathrm{pyS})\right]^{2+}$ complexes, respectively. For the SAMs formed with the 1,4-dt and pyS free ligands, the $\mathrm{E}_{\mathrm{rd}}$ values are observed at -0.87 and $-0.54 \mathrm{~V}$, respectively. ${ }^{24,31}$ The more negative value observed for the 1,4dt SAM is assigned to the $\pi$ interaction with the gold atoms. ${ }^{24}$ The coordination to a metal center with $\pi$-backbonding interaction capability strengths the Au-S bond shifting the $\mathrm{E}_{\mathrm{rd}}$ to negative values, as observed for the SAM formed with the $\left[\mathrm{Ru}(\mathrm{CN})_{5}(\mathrm{pyS})\right]^{3-}$ complex on gold $(-0.73 \mathrm{~V}){ }^{31}$ Thus, it was expected that the coordination to the $\left[\mathrm{Ru}\left(\mathrm{NH}_{3}\right)_{4}\right]^{2+}$ metal center in the $\left[\mathrm{Ru}(\mathrm{CNpy})\left(\mathrm{NH}_{3}\right)_{4}\right.$ (pyS) $]^{2+}$ complex would imply in a more expressive strengthen of the Au-S bond since the $\mathrm{NH}_{3}$ ligands, contrarily to the $\mathrm{CN}^{-}$groups, present no $\pi$ withdrawing capability. The $\mathrm{E}_{\mathrm{rd}}$ observed shift, lower than expected, is assigned to the $\pi$ withdrawing capability of the CNpy ligand trans to the pyS adsorption site in the complex. For the $\left[\mathrm{Ru}(\mathrm{CNpy})\left(\mathrm{NH}_{3}\right)_{4}(1,4-\mathrm{dt})\right]^{2+}$ complex, the $\mathrm{E}_{\mathrm{rd}}$ value is yet more positive than that observed for the 1,4-dt SAM. In this case, the competition for the $\pi$ density is much more intense because of the $\pi$ bonding of the 1,4-dt ligand with both the gold and ruthenium atoms. The effect of the electronic density on the $\mathrm{Au}-\mathrm{S}$ bond strength was also studied by Allen et al., ${ }^{6}$ who observed that a surface modifier adsorbs less strongly when an electron withdrawing group occupies the para position in relation to the sulfur adsorption site.

By integrating the area under the reductive peak, the electroactive surface coverage $(\Gamma)$ was estimated according to $\sigma_{\mathrm{rd}}=\mathrm{nFA \Gamma}$, where $\sigma_{\mathrm{rd}}$ is the charge consumed in the reductive process, $\mathrm{n}$ is the number of electrons evolved in the electrode reaction $(n=1), F$ is the Faraday constant and $\mathrm{A}$ is the geometrical area of the electrode. For the complex concentration used, the LSV curves performed after different immersion times indicated that the maximum values of the $\sigma_{\mathrm{rd}}$ and $\Gamma$ parameters are reached within 30 minutes of immersion. Thus, the $\Gamma$ maximum values for the $\left[\mathrm{Ru}(\mathrm{CNpy})\left(\mathrm{NH}_{3}\right)_{4}(1,4-\mathrm{dt})\right]^{2+}$ and $\left[\mathrm{Ru}(\mathrm{CNpy})\left(\mathrm{NH}_{3}\right)_{4}(\mathrm{pyS})\right]^{2+}$ complexes adsorbed on gold are, respectively, $9.61 \times 10^{-11}$ and $4.46 \times 10^{-11} \mathrm{~mol} \mathrm{~cm}^{-2}$. These values are one magnitude order lower than those observed for the SAMs formed with the neutral pyS free ligand and the anionic $\left[\mathrm{Ru}(\mathrm{CN})_{5}(\mathrm{pyS})\right]^{3-}$ complex on gold. ${ }^{31}$ This observation is explained based on the stronger repulsion between the adjacent cationic molecules and to the geometrical configuration of the head group (1,4-dt or pyS) that imply in different packing levels on surface 
in order to achieve a minimum energy configuration. For the $\left[\mathrm{Ru}(\mathrm{CNpy})\left(\mathrm{NH}_{3}\right)_{4}(1,4-\mathrm{dt})\right]^{2+}$ complex, for instance, the gauche orientation induces an arrangement closer together than for the $\left[\mathrm{Ru}(\mathrm{CNpy})\left(\mathrm{NH}_{3}\right)_{4}(\mathrm{pyS})\right]^{2+}$ complex which is trans in relation to the surface.

\section{SAMs electroactivity}

Cationic modifiers are, at first, expected to make difficult the assessment of the cyt c hET reaction because of its net positive charge $(+9)$ at $\mathrm{pH} 7 .{ }^{32}$ However, the cyclic voltammograms obtained with the gold surfaces modified with the $\left[\mathrm{Ru}(\mathrm{CNpy})\left(\mathrm{NH}_{3}\right)_{4}(1,4-\mathrm{dt})\right]^{2+}$ and $\left[\mathrm{Ru}(\mathrm{CNpy})\left(\mathrm{NH}_{3}\right)_{4}(\mathrm{pyS})\right]^{2+}$ complexes in the $\mathrm{KH}_{2} \mathrm{PO}_{4}$ solution containing cyt $\mathrm{c}$ presented waves assigned to the ferri/ferro redox couple of this protein, as can be seen in Figure 3.

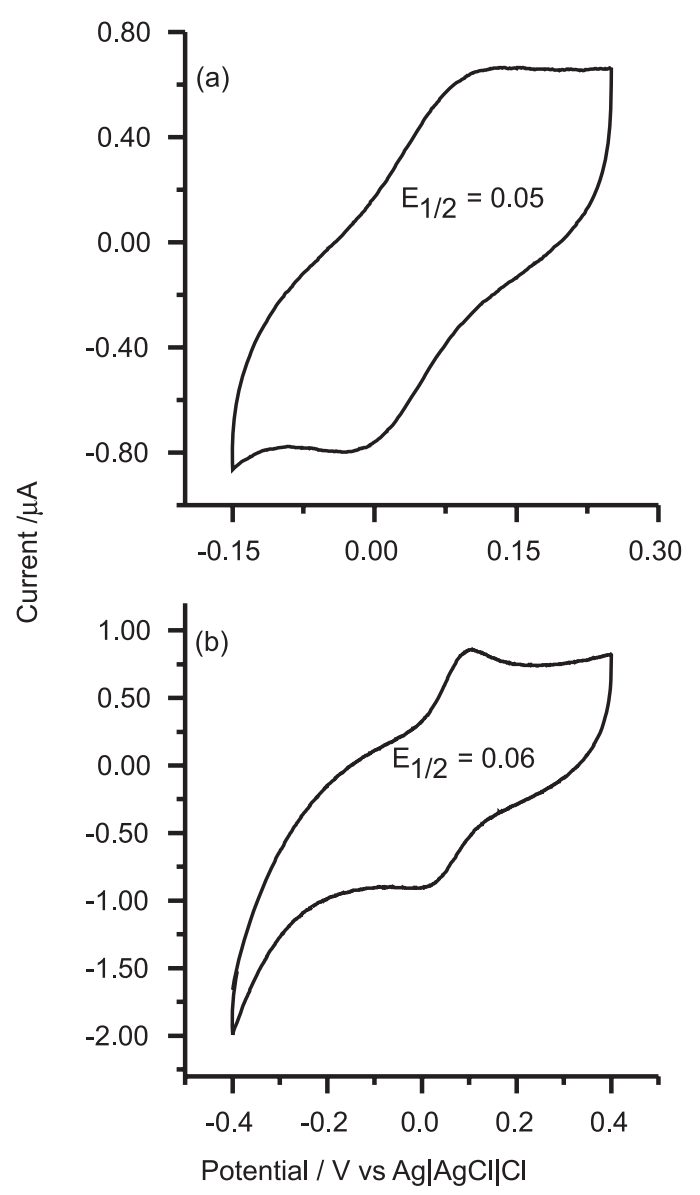

Figure 3. Cyclic voltammograms at $0.1 \mathrm{Vs}^{-1}$ of the (a) $\left[\mathrm{Ru}(\mathrm{CNpy})\left(\mathrm{NH}_{3}\right)_{4}(1,4-\mathrm{dt})\right]^{2+}$ and (b) $\left[\mathrm{Ru}(\mathrm{CNpy})\left(\mathrm{NH}_{3}\right)_{4}(\mathrm{pyS})\right]^{2+} \mathrm{SAMs}$ in $0.1 \mathrm{~mol} \mathrm{~L}^{-1} \mathrm{KH}_{2} \mathrm{PO}_{4}(\mathrm{pH}=7.0)$ containing $1.0 \times 10^{-3} \mathrm{~mol} \mathrm{~L}^{-1}$ cyt c.

For the $\left[\mathrm{Ru}(\mathrm{CNpy})\left(\mathrm{NH}_{3}\right)_{4}(1,4-\mathrm{dt})\right]^{2+} \mathrm{SAM}$, the cyt c $\mathrm{E}_{1 / 2}$ value is observed at $0.05 \mathrm{~V}$ with the waves shape (Figure 3 (a)) not well defined in the cyclic voltammogram as that obtained with the $\left[\mathrm{Ru}(\mathrm{CN})_{5}(\mathrm{pyS})\right]^{3-}$ complex as gold modifier. ${ }^{8}$ Also, there is a higher capacitive component in the cyclic voltammogram that could be assigned to the gauche orientation of the complex modifier on the surface. This conformation can raise difficulties in the achievement of an optimum modifier/protein interaction for the cyt $\mathrm{c}$ redox process recognition. For the $\left[\mathrm{Ru}(\mathrm{CNpy})\left(\mathrm{NH}_{3}\right)_{4}(\mathrm{pyS})\right]^{2+}$ modifier, the cyt $\mathrm{c} \mathrm{E}_{1 / 2}$ value is observed at $0.06 \mathrm{~V}$. In this case, the cyt $\mathrm{c}$ redox process is evidenced by a better resolved cyclic voltammogram, with a lower capacitive contribution, due to a better molecular recognition of the $\left[\mathrm{Ru}(\mathrm{CNpy})\left(\mathrm{NH}_{3}\right)_{4}(\mathrm{pyS})\right]^{2+}$ complex which is in a perpendicular orientation on surface, as suggested by the SERS results (Figure 2).

The $\mathrm{E}_{1 / 2}$ values of the cyt c protein measured by using both modifiers are indicative of the native form. To the best of our knowledge, these are the first cationic systems that assess the cyt $\mathrm{c}$ hET reaction without affecting the $\mathrm{E}_{1 / 2}$ value suggesting that there is no change in the protein conformation. By comparing with the SAM formed with the $\mathrm{S}\left(\mathrm{CH}_{2}\right)_{11} \mathrm{~N}^{+}\left(\mathrm{CH}_{3}\right)_{3}$ molecules on gold, ${ }^{33}$ for which the cyt $\mathrm{c} \mathrm{E}_{1 / 2}$ value is observed at $0.13 \mathrm{~V}$ vs $\mathrm{Ag}|\mathrm{AgCl}| \mathrm{Cl}^{-}$, the inorganic modifiers studied must detain a partial negative charge on the functional terminal group that enable a satisfactory heterogeneous molecular recognition. The cyt c electrochemical results obtained with these cationic SAMs give evidence that an anionic species is not the only condition to achieve a satisfactory molecular recognition. Also, the net surface charge seems not to be an excluding effect for the assessment of the cyt $\mathrm{c}$ hET reaction itself. Besides a negative charged end initially proposed by Jun et al. ${ }^{34}$ these results suggest that a perpendicular orientation also seems to be a determinant factor.

\section{Conclusions}

The SERS spectral data suggest the chemical configuration of the $\left[\mathrm{Ru}(\mathrm{CNpy})\left(\mathrm{NH}_{3}\right)_{4}(1,4-\mathrm{dt})\right]^{2+}$ and $\left[\mathrm{Ru}(\mathrm{CNpy})\left(\mathrm{NH}_{3}\right)_{4}(\mathrm{pyS})\right]^{2+}$ complexes on the gold surface with the 1,4-dt and pyS ligands as head groups, respectively, and the $\mathrm{CNpy}$ moiety as the terminal functional group. Also the SERS data suggest a gauche and trans conformation for the $\left[\mathrm{Ru}(\mathrm{CNpy})\left(\mathrm{NH}_{3}\right)_{4}(1,4-\right.$ $\mathrm{dt})]^{2+}$ and $\left[\mathrm{Ru}(\mathrm{CNpy})\left(\mathrm{NH}_{3}\right)_{4}(\mathrm{pyS})\right]^{2+}$ complexes on surface, respectively. This conformation assignment is the most probably reason for the best electrochemical resolution achieved with the $\left[\mathrm{Ru}(\mathrm{CNpy})\left(\mathrm{NH}_{3}\right)_{4}(\mathrm{pyS})\right]^{2+} \mathrm{SAM}$ concerning the assessment of the redox process of the cyt c metalloprotein. The $\mathrm{E}_{1 / 2}$ values observed for this process are indicative of the cyt $\mathrm{c}$ native form suggesting that the 
cationic inorganic monolayers do not induce any conformational change on the protein. Additionally, these results strongly suggest that the orientation of the modifier species on surface plays an important role on the assessment of the cyt $\mathrm{c}$ hET reaction.

As indicated by the reductive desorption potentials of the SAMs formed by the complexes on gold, the $\left[\mathrm{Ru}(\mathrm{CNpy})\left(\mathrm{NH}_{3}\right)_{4}(\mathrm{pyS})\right]^{2+}$ complex $\left(\mathrm{E}_{\mathrm{rd}}=-0.64 \mathrm{~V}\right)$ forms an $\mathrm{Au}-\mathrm{S}$ bond stronger than the $\left[\mathrm{Ru}(\mathrm{CNpy})\left(\mathrm{NH}_{3}\right)_{4}(1,4-\right.$ $\mathrm{dt})]^{2+}$ compound $\left(\mathrm{E}_{\mathrm{rd}}=-0.52 \mathrm{~V}\right)$. This result is assigned to the $\pi$ electron density withdrawing capability of the CNpy para ligand which affects more strongly the sulfur atoms of the 1,4-dt head group comparatively to the pyS sulfur atom.

\section{References}

1. Davis, J. J.; Hill, H. A. O.; Bond, A. M.; Chem. Rev. 2000, 200, 411.

2. Xu, W. S.; Zhou, H.; Regnier, F. E.; Anal. Chem. 2003, 75, 1931.

3. Liu, H. Y.; Yamamoto, H.; Wei, J. J.; Waldeck, D. H.; Langmuir 2003, 19, 2378.

4. Leopold, M. C.; Bowden, E. F.; Langmuir 2002, 18, 2239.

5. Eddowes, M. J.; Hill, H. A. O.; J. Am. Chem. Soc. 1979, 101, 4461.

6. Allen, P. M.; Hill, H. A. O.; Walton, N. J.; J. Electroanal. Chem. 1984, 178, 69 .

7. Taniguchi, I.; Iseki, M.; Yamaguchi, H.; Yasukouchi, K.; J. Electroanal. Chem. 1985, 186299.

8. Diógenes, I. C. N.; Nart, F. C.; Temperini, M. L. A.; Moreira, I. S.; Inorg. Chem. 2001, 404884.

9. Zhou, J.; Zheng, J.; Jiang, S.; J. Phys. Chem. B 2004, 108, 17418.

10. Qu, X.; Lu, T.; Dong, S.; J. Mol. Catal. 1995, 102, 111.

11. Sawyer, D. T.; Sobkowiak, A.; Roberts Jr., J. L.; Electrochemistry for Chemists, $2^{\text {nd }}$ ed., John Wiley \& Sons: NY, 1995.

12. Brautigan, D. L.; Ferguson, M. S.; Margoliash, E.; Methods Enzymol. 1978, 53, 128.

13. Von Kameke, A.; Tom, G. M.; Taube, H.; Inorg. Chem. 1978, 17, 1790.
14. Isied, S. S.; Taube, H.; J. Am. Chem. Soc. 1981, 95, 8198.

15. Huang, H.-Y.; Chen, W.-J.; Yang, C.-C.; Yeh, A.; Inorg. Chem. 1991, 30, 1862.

16. Schmidt, K. H.; Muller, A.; Coord. Chem. Rev. 1976, 19, 41.

17. Katrizky, A. R.; Chem. Rev. 1959, 13, 353.

18. Creighton, J. A. In Selection Rules for Surface-Enhanced Raman Spectroscopy. Spectroscopy of Surfaces; Clark, R. J. H.; Hester, R. E., eds.; John Wiley \& Sons: Chichester, UK, 1988.

19. Walton, R. A.; Inorg. Chem. 1966, 5, 643.

20. Christensen, P. A.; Hammett, A.; Blackhan, I.; J. Electroanal. Chem. 1991, 318, 407.

21. Hayasaki, K.; J. Chem. Soc. Jpn. 1960, 81, 1645.

22. Bryant, M. A.; Pemberton, J. E.; J. Am. Chem. Soc. 1991, 113, 3629.

23. Wong, L. S.; Vilker, V. C.; Yap, W. T.; Reipa, V.; Langmuir 1995, 11, 4818.

24. Sousa, J. R.; Batista, A. A.; Diógenes, I. C. N.; Andrade, G. F. S.; Temperini, M. L. A.; Lopes, L. G. F.; Moreira, I. S.; J. Electroanal. Chem. 2003, 543, 93.

25. Spinner, E.; J. Chem. Soc. 1960, 1237.

26. Baldwin, J.; Schuler, N.; Butler, I. S.; Andrews, M. P.; Langmuir 1996, 12, 6389.

27. Green, J. H. S.; Kyneston, W.; Paisley, H. M.; Spectrochim. Acta 1963, 19, 549.

28. Ulman, A.; Tillman, N.; Eilers, J.; Langmuir 1989, 5, 1147.

29. Ulman, A.; Chem. Rev. 1996, 96, 1533.

30. Walczak, M. M.; Alves, C. A.; Lamp, B. D.; Porter, M. D.; J. Electroanal. Chem. 1995, 396, 103.

31. Diógenes, I. C. N.; Nart, F. C.; Temperini, M. L. A.; Moreira, I. S.; Electroanalysis 2002, 14, 153.

32. Armstrong, F. A.; Struct. Bond. 1990, 72, 137.

33. Chen, X.; Ferrigno, R.; Yang, J.; Whitesides, G.; Langmuir 2002, 18, 7009.

34. Jun, F. K.; Satake, I.; Ueda, K.; Akutsu, H.; Niki, K.; Redox Chem. Int. Behavior Biol. Mol. 1984, 125.

Received: May 26, 2006

Published on the web: November 10, 2006

FAPESP helped in meeting the publication costs of this article. 